\title{
Wpływ idei prof. Ludwika Straszewicza na kierunki rozwoju badań w zakresie geografii przemysłu
}

\section{Wprowadzenie}

Profesor Ludwik Straszewicz był Uczonym, który w latach swojej działalności wywarł znaczący wpływ na kierunki prac w różnych dziedzinach nauk geograficznych. Pod jego wpływem kształtowały się postawy wielu, wówczas młodych, badaczy w krajowych ośrodków naukowych. Wynikało to z szerokiego spojrzenia profesora na różne zjawiska przestrzenne, z jego życzliwości i dzielenia się swoimi koncepcjami z młodszymi adeptami nauk geograficznych, a także tworzenia bardzo przyjaznej atmosfery na organizowanych przez jego zespół naukowy konferencjach naukowych. Jego działalność wspomagały liczne kontakty z przedstawicielami krajowych i zagranicznych (zwłaszcza francuskich) ośrodków naukowych. Dzięki temu stworzył swoją szkołę i oddziaływał nie tylko na kierunki rozwoju naukowego swoich uczniów, lecz także na wielu pracowników geograficznych w krajowych ośrodkach akademickich (Liszewski [red.] 1997; Misztal, Zioło [red.] 1998; Marszał 2001; Marszał, Niżnik 1998).

Uwzględniając wskazane przesłanki, w niniejszych rozważaniach podjęto próbę zarysowania roli prof. Ludwika Straszewicza w krzewieniu idei rozwoju badań na polu geografii ekonomicznej, zwłaszcza w zakresie geografii przemysłu.

Wykorzystując ideę prof. Straszewicza, wstępnie przyjmujemy, że historyczny proces wzrostu społecznego, gospodarczego i kulturowego dokonuje się w określonych uwarunkowaniach przyrodniczych. Ich zróżnicowanie $\mathrm{w}$ układach przestrzennych $\mathrm{w}$ różnym stopniu wpływa na nasilenie tempa i kierunki rozwoju cywilizacyjnego. W wyniku tego procesu, dokonującego się pod wpływem postępu naukowego, technologicznego, 
technicznego, społecznego i kulturowego, zmieniają się uwarunkowania kształtujące różnorodne elementy przestrzeni geograficznej. Obejmuje ona przestrzeń przyrodnicza, społeczno-gospodarczą i kulturową oraz relacje zachodzące między ich elementami. W wyniku zmienności warunków rozwoju, w różnych skalach układów przestrzennych pojawiają się różnorodne czynniki działające z określonym natężeniem. Wpływają one na różny stopień atrakcyjności danego układu przestrzennego dla działalności gospodarczej i stwarzają określone możliwości zachowania się poszczególnych elementów oraz relacji zachodzących między nimi (Lisowski [red.] 1999; Lisowski 2003; Zioło 1996a, 1999b). Postępująca złożoność procesów w strukturze układów przestrzennych doprowadziła do wydzielenia się, na gruncie nauk geograficznych, coraz bardziej szczególnych dyscyplin naukowych, których przedmiotem badań stają się coraz węższe dziedziny uwarunkowań przyrodniczych, życia gospodarczego, społecznego, kulturowego i politycznego. Należy przyjąć, że jest to proces obiektywny, który będzie się nasilał i prowadził do coraz węższych specjalizacji naukowych. Proces ten powoduje poznawanie coraz bardziej złożonych struktur przestrzennych, które są przedmiotem badań często nowych dyscyplin geograficznych.

W konsekwencji tego procesu na polu nauk geograficznych wyodrębniają się dwie tendencje. Jedna $\mathrm{z}$ nich zmierza do postępującej specjalizacji i podejmowania coraz dogłębniejszego poznawania pojawiających się problemów badawczych, druga przejawia się w dążeniu do syntezy wyników badań wyspecjalizowanych nauk geograficznych i prowadzi do wypracowywania bardziej ogólnych koncepcji, pozwalających na ujęcia syntetyzujące, celem wyjaśniania złożonych procesów kształtowania układów przestrzennych. Należy podkreślić, że ujęcia syntetyzujące procesy przemian układów przestrzennych są niezbędne i wymagają wypracowywania nowych wzorców analizy i syntezy zjawisk przestrzennych w konwencji ujęć zmienności historycznej. Prowadzi to do poznania obiektywnych przesłanek procesu przemian oraz poszukiwania nowych koncepcji budowy strategii rozwoju różnej skali układów przestrzennych o dużym znaczeniu aplikacyjnym (Domański 1982, 2012; Chojnicki [red.] 1991; Zioło 1996b, 1999b; Łoboda 2004; Maik, Rembowska, Suliborski [red.] 2006, 2007; Wilczyński 2011). Wydaje się, że brak rozwijania tego typu koncepcji badawczych doprowadził do pojawienia się wielu nowych dyscyplin naukowych, zajmujących się przestrzenią geograficzną lub jej segmentami (m.in. gospodarka przestrzenna, polityka regionalna, regionalistyka). W przeważającym stopniu wyrastały one z geografii i tworzyli je geografowie, którzy nie znajdowali swojego miejsca w strukturze tradycyjnej geografii. 
Wpływ idei prof. Ludwika Straszewicza na kierunki rozwoju...

\section{Geografia w ujęciu prof. Ludwika Straszewicza}

Trwające do dziś dyskusje wskazują na pewne trudności w zakresie określenia miejsca geografii w systemie nauk - geografia fizyczna zaklasyfikowana została do nauk przyrodniczych, a geografia ekonomiczna i społeczno-ekonomiczna do nauk ekonomicznych (m.in. Domański 1982; Kuciński 1989; Zioło 2010). W dyskusji tej, obok wielu geografów, brał także udział prof. L. Straszewicz, który mówił, że pobyt w Instytucie Geografii na Sorbonie i zajęcia prowadzone na tym uniwersytecie utwierdziły go „w jeszcze większym niż dotychczas stopniu o miejscu geografii wśród nauk humanistyczno-społecznych". Jego zdaniem, "geografia nie jest częścią nauk o ziemi, lecz częścią nauk humanistycznych, zajmującą się człowiekiem jako istotą społeczną żyjącą na ziemi" (Straszewicz 1987a: 8). W literaturze krajowej panuje pogląd, że geografia obejmuje także problemy przestrzeni przyrodniczej, co wynika z faktu, że „człowiek jako istota społeczna żyjąca na ziemi" żyje w określonych warunkach przyrodniczych.

Szkoda, że te nowe przemyślenia i poglądy prof. L. Straszewicza, dotyczące geografii, nie spowodowały pogłębionej dyskusji naukowej. Obecnie, w świetle nowych koncepcji wynikających z teorii systemów, dyskusyjne wydaje się traktowanie geografii jako nauki humanistycznej. Wynika to z braku doprecyzowanych koncepcji teoretycznych na gruncie geografii. Podkreślają to także wyniki badań J. Łobody (2004), dotyczącej stanu (przedmiotu i celu) oraz perspektyw rozwoju polskiej geografii w opinii geografów.

Ponieważ człowiek gospodaruje w środowisku przyrodniczym (przestrzeni przyrodniczej), trudno go oddzielać od podłoża jego działalności. Pomocne w tym zakresie okazało się później rozwijane i upowszechniane podejścia systemowego, pozwalającego na ujęcia holistyczne różnorodnych zjawisk. Wykorzystując jego przesłanki w przestrzeni geograficznej, można wyróżnić trzy podstawowe segmenty, obejmujące przestrzeń przyrodnicza, społeczno-gospodarczą i kulturową oraz relacje zachodzące między nimi ${ }^{1}$. Podejście to rozwija koncepcje syntetyzujące oraz umożliwia wykorzystanie wyników wyspecjalizowanych dyscyplin geograficznych do celów aplikacyjnych (budowy strategii rozwoju i zarządzania) (Zioło 1999b, 2003, 2011, 2014). Nadto wydaje się, że wiele treści wyspecjalizowanych dyscyplin geograficznych zostało w znacznej mierze przejętych

${ }^{1}$ W strukturze przestrzeni przyrodniczej wyróżniono: podłoże geologiczna, warunki klimatyczne, stosunki wodne, ukształtowanie powierzchni, gleby, świat roślin i zwierząt; w strukturze przestrzeni społeczno-gospodarczej: struktura przestrzenna rolnictwa, przemysłu, sieć komunikacyjna, sieć usług i instytucji, stosunki demograficzne, poziom wykształcenia, sieć osadnicza, zasoby kapitałowe i finansowe i kapitałowe; w przestrzeni kulturowej: zasoby kultury materialnej, kultura duchowa, aspiracje społeczeństwa, poziom wykształcenia, zasoby intelektualne oraz świadomość kulturowa, polityczna i społeczna. 
przez inne dyscypliny, które dostarczają bardziej precyzyjnych wyników (np. na gruncie demografii, mechaniki gruntów czy ekonomik szczegółowych). Brak ujęć syntetyzujących, które są niezbędne dla praktyki gospodarczej wpłynął na powstanie w obrębie nauk ekonomicznych i technicznych nowych dyscyplin, np. planowania przestrzennego, gospodarki przestrzennej, polityki przestrzennej, podstaw budowania strategii rozwoju (Zawadzki 1973; Lisowski [red.] 1999; Lisowski 2003).

Na tym tle powstaje pytanie, czy geografii nie powinno się przebudowywać i traktować jako naukę o zarządzaniu przestrzenią geograficzną (Zioło 1999b). Wydaje się, że do tej pory brak nauki, która podejmuje całościową analizę procesów zachodzących w przestrzeni geograficznej - poza nielicznymi próbami wiązania $\mathrm{z}$ nią wybranych zjawisk przyrodniczych, ekonomicznych, społecznych i kulturowych na gruncie urbanistyki. Pierwszym krokiem w tym kierunku powinno być rozwijanie teorii kształtowania przestrzeni geograficznej, dla której podstawą wyjściową może być zaproponowany przez Domańskiego (1982) alternatywny model funkcjonowania przestrzeni geograficznej, pierwotnie przedstawiony na gruncie nauk ekonomicznych (Zioło 1996a), a później geografii (Zioło 2014) i gospodarki przestrzennej (Zioło 2003) oraz koncepcja przestrzeni w geografii człowieka (Lisowski 2003). Całościowa analiza pozwala na w miarę precyzyjnie określenie procesów dokonujących się w strukturze przestrzeni geograficznej oraz ich ocenę, umożliwia przewidywanie dalszych kierunków przemian (prognozę), daje podstawę do zaproponowania racjonalnych celów rozwoju, wyboru metod ich realizacji na podstawie reguł efektywności społecznej - przyjmując jako podstawowe kryterium działalności człowieka podnoszenie poziomu i jakości życia (Domański 1982; Zioło 1999a).

$\mathrm{W}$ zaproponowanych ujęciach, w strukturze przestrzeni społeczno-gospodarczej wyróżniono strukturę przestrzenną przemysłu, której podstawowymi elementami są przedsiębiorstwa przemysłowe, relacje aktywne i pasywne zachodzące między nimi oraz elementami przestrzeni przyrodniczej, społecznej i kulturowej (Zioło 1997). Ujęcie to w pełni potwierdza traktowanie przez L. Straszewicza geografii przemysłu jako samodzielnej dyscypliny wśród nauk geograficznych, powiązanej z naukami ekonomicznymi. Podobne podejście na podstawie licznych studiów prezentuje J. Bański (2006), wyodrębniając geografię wsi.

\section{Geografia przemysłu w ujęciu prof. Ludwika Straszewicza}

Zainteresowania badawcze prof. Ludwika Straszewicza były bardzo rozległe i obejmowały $\mathrm{w}$ zasadzie wszystkie dziedziny geografii ekonomicznej. Wśród głównych nurtów badawczych ważną rolę odgrywały prace z zakresu geografii przemysłu, które dotyczyły kształtowania kom- 
Wpływ idei prof. Ludwika Straszewicza na kierunki rozwoju...

pleksu przemysłowego Łodzi (Straszewicz 1957), francuskiego przemysłowi samochodowego (Straszewicz 1965b) oraz roli przemysłu w rozwoju miast (Straszewicz 1970). Problematyka ta przewijała się także w pracach dotyczących kształtowania wielkich miast (Koter 1997), wielkich stolic (Straszewicz 1972), takich jak: Londyn (Straszewicz 1965a), Paryż (Straszewicz 1963), Moskwa (Straszewicz 1969a), Rzym (Straszewicz 1969b), Berlin (Straszewicz 1966), Madryt (Straszewicz 1981), Lizbona (Straszewicz 1980) czy Lyon (Straszewicz 1987b). Analizując kształtowanie się wielkich miast, dużą rolę w wyjaśnianiu ich procesów rozwoju i coraz bardziej złożonych struktur przestrzennych wiązał z procesami industrialnego rozwoju, które przedstawiał w różnych uwarunkowaniach gospodarczych, zarówno w warunkach gospodarki rynkowej, jak i w warunkach gospodarki centralnie sterowanej.

Biorąc pod uwagę czas, w którym L. Straszewicz prezentował swoje stanowisko (koniec okresu gospodarki centralnie sterowanej), trzeba stwierdzić, że zaproponowane przez profesora ujęcie geografii przemysłu jako dyscypliny jest nowatorskie (Straszewicz 1986, 1987a). W znacznym zakresie nawiązuje ono do współczesnych warunków wdrażanie reguł gospodarki rynkowej. Wobec toczących się dyskusji nad przedmiotem geografii ekonomicznej, uzasadniał swoje stanowisko, twierdząc, ,"że geografia przemysłu należąca do geografii ekonomicznej, będąca integralną częścią długiego łańcucha nauk geograficznych, jest jednocześnie, a może nawet przede wszystkim, nauką ekonomiczna, jednym z działów wiedzy, zajmującej się gospodarczą działalnością społeczeństwa [...] jako dyscyplina ekonomiczna geografia przemysłu zajmuje się produkcyjną działalnością człowieka, w aspekcie jej związków z całym kompleksem działalności ludzkiej oraz w ścisłym kontekście z tym, co dzisiaj nazywamy środowiskiem" (Straszewicz 1987a: 9). Następnie przyjmuje, że podstawą istoty działalności ekonomicznej jest podejmowanie decyzji i ponoszenie wszelkich z nimi związanych konsekwencji, m.in. w dziedzinie kosztów. Tak pojęta działalność ekonomiczna obejmuje zagadnienie rozmieszczenia zakładów przemysłowych, które rzutują na wielkość i strukturę kosztów, rentowność, wielkość zainwestowanego kapitału itp. Uważa, że „na gruncie zainteresowań rozmieszczeniem zakładów produkcyjnych, określonym przez nas mianem lokalizacji, występują również geografowie i stykają się tu z ekonomistami" (Straszewicz 1987a: 9). Interesujące są poglądy L. Straszewicza, który mówi: „Przed pięciu laty twierdziłem, że geografia przemysłu jest, względnie powinna być, bliższa ekonomii politycznej, niż to sądzi wielu geografów uprawiających tę dyscyplinę. Dziś [...] skłonny byłbym sformułować je bardziej stanowczo, [...] że geografia przemysłu opiera się w całości na teoriach ekonomicznych (lokalizacja przemysłu)". W wyniku swoich przemyśleń i pogłębionych badań 
twierdzi, że „Ze względu na odmienny, wyraźnie określony i łatwo wydzielający się przedmiot badań, a także ze względu na ścisły kontekst z naukami ekonomicznymi, socjologia, a nawet psychologią oraz związki z określonymi działami techniki - geografia przemysłu jest zdecydowanie odrębnym działem geografii" (Straszewicz 1987a: 10) .

Przedstawione stanowisko L. Straszewicza w pełni uzasadnia genezę i pole zainteresowań badawczych geografii przemysłu jako samodzielnej nauki, wyodrębnionej w strukturze nauk geograficznych. Należy zaznaczyć, że prace na polu geografii przemysłu stawiają badaczom duże wymagania, związane z koniecznością poznania wielu procesów technologicznych, ekonomicznych i społecznych oraz pokonywania wielu trudności (które szczególnie nasiliły się w ostatnich latach) w zakresie dostępności do danych empirycznych. W czasach gospodarki centralnie sterowanej trudności te wiązały się ze względami obronnymi, a w latach gospodarki rynkowej - z ograniczeniami, wynikającymi z chęci zachowania tajemnicy przedsiębiorstwa (wobec nasilających się reguł konkurencyjności), zachodzące między przedsiębiorstwami oraz instytucjami finansowymi. Wpływało to na osłabienie zainteresowania problematyką geografii przemysłu w krajowych ośrodkach akademickich, na które, także w następnych latach, oddziaływały głoszone poglądy, płynące z krajów

184 ekonomicznie rozwiniętych o zmniejszającym się wpływie procesów industrializacji na rozwój gospodarczy i przechodzeniu do postindustrialnej fazy rozwoju. Wynikało to zapewne $z$ niedostatecznego poznania tych idei, które równocześnie zakładały wchodzenie w informacyjną fazę społecznego rozwoju, co umożliwiały nowe sektory przemysłowe, w tym rozwój przemysłu informatycznego.

\section{Idea prof. Ludwika Straszewicza - Komisja Geografii Przemysłu i rozwój jej działalności}

Zdaniem prof. Ludwika Straszewicza, nie można było dopuścić do ograniczania prac na polu geografii przemysłu, związanych zwłaszcza z pojawiającymi się trudnościami w zakresie dostępu do bazy danych empirycznych oraz coraz bardziej złożonymi metodami badawczymi. Mając duże doświadczenie w zakresie podejmowania różnorodnej problematyki badawczej na polu geografii ekonomicznej i społecznej, wzbogacone także pobytem w Paryżu (profesor Sorbony), podjął inicjatywę zintensyfikowania badań w zakresie geografii przemysłu w krajowych ośrodkach akademickich. Z inicjatywy profesora na posiedzeniu dnia 21 stycznia 1979 r., w Zakładzie Geografii Ekonomicznej i Organizacji Przestrzeni Instytutu Geografii Uniwersytetu Łódzkiego, powstała grupa inicjatywna 
Wpływ idei prof. Ludwika Straszewicza na kierunki rozwoju...

utworzenia krajowego forum prezentacji wyników badawczych tej dyscypliny. W konsekwencji starań Straszewicza, 24 marca 1979 r. została podjęta uchwała Zarządu Głównego Polskiego Towarzystwa Geograficznego o powołaniu Komisji Geografii Przemysłu Polskiego Towarzystwa Geograficznego (Misztal 1998). Na jej pierwszego przewodniczącego został wybrany prof. dr hab. Ludwik Straszewicz, a w skład zarządu weszli, jako wiceprzewodniczący, prof. dr hab. Stanisław Misztal (IGiPZ PAN Warszawa) i doc. dr hab. Lech Pakuła (WSP Kraków), funkcję sekretarza naukowego powierzono dr Stanisławowi Pączce (UŁ Łódź), a zastępcą sekretarza została mgr Anna Niżnik (UŁ Łódź). Podjęto również decyzję o organizowaniu ogólnopolskich konferencji naukowych oraz publikowaniu wyników prac badawczych.

Działalność Komisji przejawiała się głównie w organizowaniu konferencji naukowych, początkowo krajowych, a później międzynarodowych. Obecnie są one uznaną platformą prezentacji wyników badań naukowych i wymiany poglądów dotyczących problematyki geografii przemysłu i usług. Pomysł prof. Ludwika Straszewicza znalazł więc podatny grunt i nadal się rozwija. W latach 1984-2014 odbyło się 30 konferencji naukowych, początkowo organizowane $\mathrm{w}$ ramach prac Centralnego Ośrodka Metodycznego Studiów Nauczycielskich, którego dyrektorem przez trzy kadencje był Z. Zioło. Początkowe prace Komisji Geografii Przemysłu były publikowane w ramach serii "Sprawozdania i Materiały" COMSN ${ }^{2}$ a następnie w serii „Prace Komisji Geografii Przemysłu” PTG, przy współudziale Zakładu Przedsiębiorczości i Gospodarki Przestrzennej Instytutu Geografii obecnego Uniwersytetu Pedagogicznego, którego organizatorem i kierownikiem był Z. Zioło (następnie funkcję kierowniczą przejął T. Rachwał).

Pierwsza konferencja nowo powstałej Komisji Geografii Przemysłu PTG oraz spotkanie członków Komisji Geografii Przemysłu odbyło się w 1985 r. w Krakowie i było poświęcone problematyce geografii przemysłu w akademickim kształceniu nauczycieli. Dokonano na niej pewnego podsumowania osiągnięć badawczych, zarysowano dotychczasowe kierunki badawcze tej dyscyplinie oraz zaproponowano nowe ujęcia i treści edukacyjne w dydaktyce akademickiej (Zioło [red.] 1987). Programowe wystąpienie dotyczące geografii przemysłu, jako nauki i dyscypliny nauczania przedstawił L. Straszewicz, który określił zadania geografii przemysłu oraz jej związki z naukami ekonomicznymi. Kolejne wystąpienia

${ }^{2}$ W tej serii pod red. Z. Zioło ukazało się 11 tomów wydawanych w ramach Centralnego Ośrodka Metodycznego Studiów Nauczycielskich i Komisji Geografii PTG, 28 tomów w serii „Prace Komisji Geografii Przemysłu” (red. Zioło - 4 tomy, Zioło, Makieła - 3 tomy, Z. Zioło, T. Rachwał - 25 tomów), a także Misztal, Zioło [red.] 1998 oraz Marszał 2001. 
dotyczyły aktualnych kierunków i problemów badawczych geografii przemysłu (Kortus 1987), kierunków badawczych geografii przemysłu w Polsce w latach 1945-1980 (Stryjakiewicz 1987), wykładowym treściom kształcenia w zakresie geografii przemysłu (Pakuła, Zioło 1987) i ćwiczeniom (Adamus, Troc 1987) oraz treści geografii przemysłu w nowych programach nauczania w szkole podstawowej i średniej (Piskorz 1987). Nadto dokonano prezentacji problematyki geografii przemysłu w wybranych krajach Europu Zachodniej (Grzeszczak 1987), w Czechosłowacji (Niżnik, Makieła 1987) i w Niemczech (Zikandeloff 1987).

Pod wpływem idei prof. L. Straszewicza znacznie ożywiły się badania dotyczące problematyki geografii przemysłu, a także problematyki usług, prezentowane na kolejnych corocznych konferencjach naukowych. Obejmowały one coraz szerszy zakres tematyczny, a ich uczestnikami w coraz większym stopniu stawali się przedstawiciele nauk ekonomicznych, politologii i socjologii.

Problematyka pierwszych konferencji dotyczyła: kształcenia nauczycieli geografii na poziomie akademickim, problematyki badawczej zakładu przemysłowego, ośrodka i okręgu przemysłowego jako przestrzennych form koncentracji przemysłu, regionalnych problemów uprzemysłowienia oraz problematyki przemysłu rolno-spożywczego.

186 W latach wdrażania reguł gospodarki rynkowej rozszerzała się problematyka konferencji o aktualną tematykę, dotyczącą: geografii przemysłu w warunkach wdrażania nowego systemu gospodarowania, funkcjonowania przedsiębiorstw przemysłowych $\mathrm{w}$ warunkach gospodarki rynkowej, wpływu procesów transformacji gospodarki na funkcjonowanie jednostek gospodarczych i układów przestrzennych. Kolejne konferencje poświęcone były problematyce transformacji struktur przemysłowych $\mathrm{w}$ procesie przechodzenia do gospodarki rynkowej oraz procesom transformacji przemysłu i usług $\mathrm{w}$ regionalnych i krajowych układach przestrzennych..

Nagromadzenie wielu wyników prac empirycznych wskazało na konieczność rozwijania koncepcji metodologicznych, czego wyrazem były konferencje poświęcone osiagnięciom i kierunkom badawczym oraz problemom metodologicznym geografii przemysłu.

Problematyka ostatnich konferencji nawiązywała do: wpływu procesów globalizacji, integracji europejskiej i zmian międzynarodowych uwarunkowań na kontynuację procesów transformacji struktur przemysłowych w układach regionalnych i krajowych, wpływie kryzysu na funkcjonowanie przedsiębiorstw i zmian struktur przestrzennych, wpływie innowacyjności na rozwój przedsiębiorstw i gospodarki w układach przestrzennych oraz zmiany działalności przemysłowej i usług w gospodarce opartej na wiedzy. Do problematyki tej nawiązywały także prace po- 
Wpływ idei prof. Ludwika Straszewicza na kierunki rozwoju...

wstające w SGH, poświęcone zagadnieniom przemysłu (Fierla 1987, 1994, 1996; Kuciński [red.] 1993, 2004, 2006).

W wielu dyskusjach podkreślano, że w warunkach gospodarki rynkowej procesy transformacji struktur przemysłowych w układach przestrzennych oraz kształtowania przedsiębiorstw są związane z jakością kadr zarządzających, które powinny odznaczać się odpowiednio ukształtowanymi cechami postaw przedsiębiorczych. Uznano również, że rozszerza to problematykę geografii przemysłu. Było to impulsem do uruchomienia w ramach prac Komisji Geografii Przemysłu nowego cyklu konferencji i nowej serii wydawniczej pod nazwą "Przedsiębiorczość - Edukacja". Rozwijana jest w nich nowa problematyka badawcza geografii przemysłu, dotycząca przedsiębiorczości w warunkach współczesnych wyzwań cywilizacyjnych oraz roli przedsiębiorczości w podnoszeniu konkurencyjności społeczeństwa i gospodarki, rozwoju gospodarki opartej na wiedzy, kształtowaniu postaw etycznych, kształtowaniu społeczeństwa informacyjnego w warunkach integracji europejskiej, nasilania procesów globalizacji oraz roli edukacji i kryzysu gospodarczego w rozwoju firm w układach przestrzennych. Problematyka ta nawiązuje także do nowej specjalności - geografii z przedsiębiorczością i gospodarką przestrzenna, utworzonej w strukturze Instytutu Geografii Uniwersytetu Pedagogicznego.

\section{Relacje geografii przemysłu z ekonomią}

Przedstawione poglądy prof. L. Straszewicza inspirują do pogłębiania problematyki relacji, zachodzących między geografią przemysłu a ekonomią. Generalnie można przyjąć, że ekonomia analizuje procesy od strony mechanizmów, w mniejszym stopniu uwzględniając ich przestrzenne uwarunkowania, natomiast geografia w zasadniczym stopniu stawia akcent na zróżnicowaną przestrzeń przyrodnicza, społeczno-gospodarczą i kulturową. Na tym tle na gruncie geografii przemysłu pojawia się możliwość nowego podejścia badawczego.

Zakładamy, że wszystkie procesy ekonomiczne, społeczne i kulturowe kształtują się w określonym czasie i w określonym miejscu przestrzeni geograficznej pod wpływem czynników i różnorodnych reguł rozwoju ekonomicznego. Procesy ekonomiczne, w zależności od jakości i potencjału elementów przestrzeni geograficznej, kształtują procesy przemian, przejawiające się $\mathrm{w}$ przestrzennym różnicowaniu dynamiki i poziomu rozwoju. Wyłania to dwa podejścia metodologiczne: pierwsze, rozpatrujące zmienność struktury przestrzennej przemysłu dokonującą się pod wpływem reguł ekonomicznego rozwoju, oraz drugie, rozstrzygające, w jakim 
stopniu reguły ekonomicznego rozwoju - wykorzystując zróżnicowane uwarunkowania przestrzenne - wpływały na różnicowanie struktury przestrzennej przemysłu.

Na proces kształtowania struktury przestrzennej przemysłu $\mathrm{w}$ podstawowym stopniu wpływają reguły: mikroekonomiczne - odnoszące się do funkcjonowania i rozwoju przedsiębiorstwa przemysłowego; mezoekonomiczne - wpływające na kształtowanie przestrzennych form koncentracji przemysłu i gospodarki w układach regionalnych; makroekonomiczne - według których kształtuje się gospodarka krajowa; megaekonomiczne - odnoszące się do kształtowania gospodarki, np. przestrzeni Unii Europejskiej oraz ekonomii światowej - kształtującą światową przestrzeń społeczno-gospodarczą (Zioło 1996a).

Podstawowymi elementami struktury przestrzennej przemysłu sac przedsiębiorstwa przemysłowe, które w zasadniczym stopniu kształtują reguły mikroekonomiczne. Reguły te wyznaczają podstawowe cele działalności przedsiębiorstwa przemysłowego, które związane są z dążeniem do osiągania maksymalnego zysku i możliwości osiąganie określonych korzyści ekonomicznych. W wyniku tych reguł przedsiębiorca podejmuje samodzielnie decyzje o lokalizacji firm, kierunkach rozwoju, rozmiarach i asortymencie produkcji, prowadząc działalność na własny rachunek

Regułami mezoekonomicznymi kierują się układy regionalne, w tym przestrzenne formy koncentracji przemysłu (m.in. ośrodki i okręgi przemysłowe, klastry), a także układy lokalne i regionalne. Podstawowym celem rozwoju układów przestrzennych jest zapewnienie rozwoju, m.in. poprzez koordynację działalności podmiotów gospodarczych i instytucji, a także stwarzanie korzystnych warunków do prowadzenia działalności gospodarczej, np. w zakresie infrastruktury technicznej i społecznej, co przyczynia się do zwiększania strumieni finansowych płynących do ich budżetu, co powoduje podnoszenie poziomu i jakości życia ludności.

Regułami makroekonomicznymi charakteryzuje się działalność państwa, którego podstawowym zadaniem jest dbanie o zwiększanie dochodu narodowego, jego racjonalny podział, określanie budżetu i polityki fiskalnej, ograniczanie inflacji i bezrobocia oraz tworzenie warunków rozwijania korzystnej współpracy i wymienny międzynarodowej. Służą temu różnorodne instrumenty bezpośredniego i pośredniego oddziaływania, prowadzące do intensyfikowania rozwoju gospodarczego i stwarzania korzystnych warunków do rozwijania działalności gospodarczej przedsiębiorstw, a także podnoszenia jakości funkcjonowania instytucji, co w konsekwencji prowadzi do poprawy poziomu i jakości życia społeczności krajowej.

Regułami megaekonomicznymi rządzą się bardziej złożone struktury gospodarcze, np. Unia Europejska. Ich celem jest dynamizowanie wzrostu 
Wpływ idei prof. Ludwika Straszewicza na kierunki rozwoju...

gospodarczego i społecznego, podnoszenie konkurencyjności gospodarki europejskiej w stosunku do światowych biegunów wzrostu gospodarczego (Stanów Zjednoczonych, Japonii, krajów BRICS), pobudzanie wzrostu gospodarczego na rzecz wyrównywania przestrzennych dysproporcji w rozwoju przestrzennym, a także dbanie o bezpieczeństwo.

W nawiązaniu do reguł ekonomii światowej, kształtują się światowe bieguny wzrostu gospodarczego, między którymi zachodzą nie tylko relacje współpracy i wymiany produktów, zasobów pracy, strategicznych dla świata surowców, lecz także relacje konkurencji w zakresie oferowanych produktów i rynków, dążenie do wzrostu gospodarczego i in. Reguły te prowadzą także do ograniczania światowych konfliktów i zagrożeń, wynikających np. z postępujących procesów polaryzacji przestrzennej, nasilania się zjawisk patologii społecznej, zmian warunków klimatycznych, emisji zanieczyszczeń, ograniczania i zagospodarowania odpadów itp. (tab. 1).

Tabela 1. Relacje między regułami rozwoju ekonomicznego

\begin{tabular}{|l|c|c|c|c|c|c|}
\hline \multirow{2}{*}{ Reguły rozwoju } & Mikro- & Mezo- & Makro- & Mega- & Światowa \\
\cline { 3 - 7 } & $\mathrm{X}_{1}$ & $\mathrm{X}_{2}$ & $\mathrm{X}_{3}$ & $\mathrm{X}_{4}$ & $\mathrm{X}_{5}$ \\
\hline Mikro- & $\mathrm{X}_{1}$ & $\mathrm{x}_{12}$ & $\mathrm{x}_{13}$ & $\mathrm{x}_{14}$ & $\mathrm{x}_{15}$ & $\mathrm{x}_{16}$ \\
\hline Mezo- & $\mathrm{X}_{2}$ & $\mathrm{x}_{21}$ & $\mathrm{x}_{22}$ & $\mathrm{x}_{23}$ & $\mathrm{x}_{24}$ & $\mathrm{x}_{25}$ \\
\hline Makro- & $\mathrm{X}_{3}$ & $\mathrm{x}_{31}$ & $\mathrm{x}_{32}$ & $\mathrm{x}_{33}$ & $\mathrm{x}_{34}$ & $\mathrm{x}_{35}$ \\
\hline Mega- & $\mathrm{X}_{4}$ & $\mathrm{x}_{41}$ & $\mathrm{x}_{42}$ & $\mathrm{x}_{43}$ & $\mathrm{x}_{44}$ & $\mathrm{x}_{45}$ \\
\hline Światowa & $\mathrm{X}_{5}$ & $\mathrm{x}_{51}$ & $\mathrm{x}_{52}$ & $\mathrm{x}_{53}$ & $\mathrm{x}_{54}$ & $\mathrm{x}_{55}$ \\
\hline
\end{tabular}

Mechanizmy działania reguł mikroekonomicznych opisują relacje $\left[\mathrm{x}_{11}\right]$; mezoekonomicznych - relacje $\left[\mathrm{x}_{22}\right]$; makroekonomicznych - relacje $\left[\mathrm{x}_{33}\right]$; megaekonomicznych - relacje $\left[\mathrm{x}_{44}\right]$; ekonomii światowej-relacje $\left[\mathrm{x}_{55}\right]$.

Wśród wyróżnionych reguł rozwoju ekonomicznego występują złożone relacje aktywne i pasywne, które mogą wpływać na wzrost ekonomiczny przedsiębiorstw, układów lokalnych, regionalnych i poszczególnych krajów, ale także na ich stagnację lub recesję.

Aktywne oddziaływanie poszczególnych kategorii reguł opisuja wiersze tab. 1, np. oddziaływanie reguł mikroekonomicznego rozwoju $\left(X_{1}\right)$ na pozostałe $\left(X_{2}, \ldots, X_{5}\right)$ opisują relacje $\left[x_{12}\right]$ - przestawiające ich oddziaływanie na reguły mezoekonomiczne; na reguły makroekonomiczne - $\left[\mathrm{x}_{13}\right]$; oddziaływanie na reguły megaekonomiczne $-\left[\mathrm{x}_{14}\right]$ i na reguły ekonomii światowej - $\left[\mathrm{x}_{15}\right]$.

Również reguły mezoekonomiczne $\left(\mathrm{X}_{2}\right)$ wpływają na reguły: mikroekonomiczne $\left[\mathrm{x}^{\mathrm{x}}{ }_{21}\right]$, makroekonomiczne $\left[\mathrm{x}_{23}^{\mathrm{x}}\right]$, megaekonomiczne $\left[\mathrm{x}_{24}^{\mathrm{x}}\right]$ i reguły gospodarki światowej $\left[\mathrm{x}_{25}^{\mathrm{x}}\right]$. 
Podobnie oddziałują na siebie reguły makroekonomiczne $\left(X_{3}\right)$, megaekonomiczne $\left(\mathrm{X}_{4}\right)$ i reguły gospodarki światowej $\left(\mathrm{X}_{5}\right)$.

Pasywne oddziaływanie poszczególnych reguł na daną kategorię opisują kolumny tab. 1, np. oddziaływanie pozostałych kategorii reguł $\left(X_{2}, \ldots, X_{5}\right)$ na reguły mikroekonomiczne $\left(X_{1}\right)$, opisują relacje: $\left[x_{21}\right]$ - oddziaływanie reguł mezoekonomicznych, $\left[\mathrm{x}_{31}^{\mathrm{x}}\right]$ - oddziaływanie reguł makroekonomicznych, $\left[\mathrm{x}_{41}^{\mathrm{x}}\right]$ - oddziaływanie reguł megaekonomicznych i $\left[\mathrm{x}_{51}^{\mathrm{x}}\right.$ ] - oddziaływanie reguł ekonomii światowej.

Podobnie zaznaczają się pasywne oddziaływania poszczególnych kategorie reguł na daną kategorię.

Oznacza to, że $\left[\mathrm{x}_{12}\right]$ nie równa się $\left[\mathrm{x}_{21}\right]$. Relacja pierwsza określa wpływ reguł mikroekonomicznych na reguły makroekonomiczne, a druga relacje odwrotne, wpływ reguł makroekonomicznych na mikroekonomiczne.

Między regułami rozwoju ekonomicznego zachodzą pewne konflikty, które należy ograniczać w wyniku odpowiednich negocjacji. Wynikają one z faktu, że np. przedsiębiorstwo, które rządzi się regułami mikroekonomicznymi $\left(X_{1}\right)$ jest zainteresowane np. zmniejszeniem podatków i opłat z tytułu prowadzenia działalności gospodarczej na rzecz układu lokalnego czy regionalnego $\left[x_{12}\right]$, podczas gdy układy lokalne czy regionalne, rozwijające się według reguł mezoekonomicznych $\left(X_{2}\right)$, są zainteresowane

190 zwiększaniem obciążeń finansowych przedsiębiorstw na rzecz zwiększania dochodów płynących do ich budżetu $\left[\mathrm{x}_{21}\right]$.

Również układy lokalne czy regionalne $\left[\mathrm{x}_{22}\right] \mathrm{w}$ celu podniesienia swojej atrakcyjności oraz napływu zewnętrznych czynników rozwoju mogą obniżyć wysokość opłat wnoszonych do budżetu samorządowego lub dokonać inwestycji infrastrukturalnych, niezbędnych do obniżenia ich kosztów inwestowania $\left[\mathrm{x}_{21}\right]$.

Podobnie Unia Europejska, rządząca się regułami megaekonomicznymi (X4), może wpływać na reguły makroekonomiczne, którymi rządzą się poszczególne państwa członkowskie $\left(\mathrm{X}_{3}\right)$ w drodze aktywnego oddziaływania, przejawiającego się $n p$. $w$ dążeniu do obniżania emisji $\mathrm{CO}_{2}\left[\mathrm{x}_{43}\right]$. Poszczególne kraje mogą też oddziaływać na Unię, dążąc np. do obniżenia swoich składek członkowskich, płaconych na jej rzecz $\left[\mathrm{x}_{34}\right]$.

Oznacza to, że wzrost potencjału ekonomicznego i powiązań gospodarczych, dokonujących się w strukturze przestrzennej przemysłu, realizują się według określonych reguł rozwoju ekonomicznego, w oparciu o podstawowe kryterium, jakim jest możliwość osiągania korzyści finansowych w bliższej lub dalszej perspektywie czasowej. Wydaje się, że zaprezentowane podejście pozwala na lepsze zrozumienie i wyjaśnianie procesów wzrostu gospodarczego oraz powiązań ekonomicznych, dokonujących się między podmiotami gospodarczymi i różnymi skalami układów przestrzennych. 
Wpływ idei prof. Ludwika Straszewicza na kierunki rozwoju...

W procesie zarządzania, w celu osłabienia działania restrykcyjnych reguł ekonomicznych, ważną rolę odgrywają negocjacje, które poprzez określone ustalenia powinny zmierzać do osiągania kompromisów, np., z jednej strony, zgody na ograniczanie wielkości zysków, a z drugiej - zgody na zmniejszanie dochodów budżetowych układów przestrzennych. Ograniczenia te wymagają rozważnych decyzji, wynikających z dialogu społecznego w oparciu o analizę jakości zarządzania, osiąganych efektów ekonomicznych oraz możliwości rozwoju społecznego układów przestrzennych.

\section{Uwagi końcowe}

Przedstawione rozważania potwierdzaja, że idee prof. Ludwika Straszewicza, zarysowujące relacje geografii ekonomicznej, a szczególnie geografii przemysłu z naukami ekonomicznymi, znacznie rozszerzają pole zainteresowań geografii przemysłu. Wskazuja, że wszelka działalność gospodarcza winna być podejmowana i oceniana poprzez rachunek ekonomiczny oraz efektywność działania procesów gospodarczych, ale także społecznych i kulturowych. Na tej podstawie w badaniach geograficznych, a także $w$ ramach gospodarki przestrzennej, związanych $\mathrm{z}$ analizą procesów przemian, należy przyjąć, że prawa ekonomicznego rozwoju określają mechanizmy procesu i mają charakter przestrzenny, natomiast realizują się w zróżnicowanych uwarunkowaniach przestrzennych. W konsekwencji, te same instrumenty i wzorce ekonomiczne, dające pozytywne rezultaty w jednych uwarunkowaniach przestrzennych, mogą dać zgoła niekorzystne rezultaty w innych uwarunkowaniach. Oznacza to, że nie można wzorców z krajów ekonomicznie rozwiniętych przenosić i wdrażać do kształtowania procesów ekonomicznych i społecznych $\mathrm{w}$ krajach stojących na niższym poziomie rozwoju gospodarczego czy kulturowego. Negatywne wyniki takich działań zaznaczyły się już w wielu krajach, w których podejmowano procesy restrukturyzacji gospodarki na wzór krajów ekonomicznie rozwiniętych, nie tylko w Europie, lecz także w Azji i Afryce. Wyrazem tego jest nasilanie się procesów polaryzacji, które prowadzą do niezadowoleń społecznych. Oznacza to, że podejście zarysowane przez prof. Straszewicza otwiera nowe pola badawcze dla geografii ekonomicznej, a szczególnie dla geografii przemysłu oraz daje możliwości dalszych poszukiwań metodologicznych, pozwalających na precyzyjniejsze poznanie procesów przestrzennych dokonujących się zwłaszcza w warunkach gospodarki rynkowej. Ma to szczególne znaczenie wobec pojawiających się tendencji pobudzania procesów reindustrializacji, które będą nawiązywać do reguł kształtowania społeczeństwa informacyjnego i gospodarki opartej na wiedzy. 


\section{Literatura}

Adamus J., Troc M. (1987), Analiza programów ćwiczeń z geografii przemystu w uniwersytetach $i$ wyższych szkołach pedagogicznych, [w:] Z. Zioło (red.), Geografia przemystu w akademickim kształceniu nauczycieli, Centralny Ośrodek Metodyczny Studiów Nauczycielskich WSP, „Materiały i Sprawozdania” 14, Wyd. Naukowe WSP w Krakowie, Kraków, s. $71-76$.

Bański J. (2006), Geografia polskiej wsi, PWE, Warszawa.

Chojnicki Z. [red.] (1991), Podstawowe problemy metodologiczne rozwoju polskiej geografii, Wyd. Naukowe Uniwersytetu Adama Mickiewicza, Poznań.

Domański R. (1982), Teoretyczne podstawy geografii ekonomicznej, PWE, Warszawa.

Domański R. (2012), Ewolucyjna gospodarka przestrzenna, Wyd. Uniwersytetu Ekonomicznego w Poznaniu, Poznań.

Fierla I. (1987), Lokalizacja przemystu, PWE, Warszawa.

Fierla I. (1994), Zmiany uwarunkowań lokalizacji przemystu w Polsce, cz. I, SGH, Warszawa.

Fierla I. (1996), Zmiany uwarunkowań lokalizacji przemystu w Polsce, cz. II, SGH, Warszawa.

Grzeszczak J. (1987), Problematyka przemystowa na studiach geograficznych w wybranych krajach Europy Zachodniej, [w:] Z. Zioło (red.), Geografia przemystu w akademickim kształceniu nauczycieli, Centralny Ośrodek Metodyczny Studiów Nauczycielskich WSP, „Materiały i Sprawozdania" 14, Wyd. Naukowe WSP w Krakowie, Kraków, s. 77-83.

Kortus B. (1987), Aktualne kierunki i problemy badawcze geografii przemystu, [w:] Z. Zioło (red.), Geografia przemystu w akademickim kształceniu nauczycieli, Centralny Ośrodek Metodyczny Studiów Nauczycielskich WSP, „Materiały i Sprawozdania” 14, Wyd. Naukowe WSP w Krakowie, Kraków, s. 14-21.

Koter M. (1997), Profesor Ludwik Straszewicz w siedemdziesięciolecie urodzin i trzydziestolecie objęcia kierownictwa Katedry Geografii Ekonomicznej Uniwersytetu Łódzkiego, „Sylwetki Łódzkich Uczonych", z. 41: Profesor Ludwik Straszewicz, red. S. Liszewski, ŁTN, Łódź, s. 13-22.

Kuciński K. [red.] (1993), Strukturalne uwarunkowania lokalizacji firm, Wydział Ekonomiki Produkcji SGH, Warszawa.

Kuciński K. [red.] (2004), Polskie przedsiębiorstwa wobec szoku akcesyjnego, Instytut Funkcjonowania Gospodarki Narodowej, SGH, „Materiały i Prace”, t. 88.

Kuciński K. [red.] (2006), Polskie przedsiębiorstwa wobec globalnej konkurencji, Instytut Funkcjonowania Gospodarki Narodowej, SGH, „Materiały i Prace”, t. 45.

Kuciński K. (1989), Geografia ekonomiczna - zarys teoretyczny, SGPiS, Warszawa.

Lisowski A. [red.] (1999), Geografia na przełomie wieków - jednorodność w różnorodności, Wydział Geografii i Studiów Regionalnych Uniwersytetu Warszawskiego, Warszawa.

Lisowski A. (2003), Koncepcje przestrzeni w geografii człowieka, Wydział Geografii i Studiów Regionalnych Uniwersytetu Warszawskiego, Warszawa.

Liszewski S. [red.] (1997), Profesor Ludwik Straszewicz, „Sylwetki Łódzkich Uczonych”, z. 41, ŁTN, Łódź.

Łoboda J. (2004), Stan i perspektywy polskiej geografii w opinii geografów, „Przegląd Geograficzny", z. 4, s. 389-414.

Maik W., Rembowska K., Suliborski A. [red.] (2006), Człowiek w badaniach geograficznych. Podstawowe idee i koncepcje w geografii, t. 2, Wyższa Szkoła Gospodarki, Bydgoszcz.

Maik W., Rembowska K., Suliborski A. [red.] (2007), Geografia a przemiany wspótczesnego świata. Podstawowe idee i koncepcje w geografii, t. 3, Wyższa Szkoła Gospodarki, Bydgoszcz. 
Wpływ idei prof. Ludwika Straszewicza na kierunki rozwoju...

Marszał T. (2001), Polska geografia przemystu i budownictwa w XX w. - sylwetki, Komisja Geografii Przemysłu PTG, Wydział Nauk Geograficznych UŁ, Łódź-Warszawa-Kraków.

Marszał T., Niżnik A. (1998), Dorobek i kierunki rozwoju geografii przemystu w Łódzkim Ośrodku Geograficznym, [w:] S. Misztal, Z. Zioło (red.), Dorobek polskiej geografii przemystu w badaniach ośrodków akademickich, Komisja Geografii Przemysłu PTG, Wyd. Krakowskiego Oddziału PAN, Warszawa-Kraków, s. 121-145.

Misztal S. (1998), Działalność Komisji Geografii Przemysłu, 1979-1966, [w:] S. Misztal, Z. Zioło (red.), Dorobek polskiej geografii przemysłu w badaniach ośrodków akademickich, Komisja Geografii Przemysłu PTG, Wyd. Krakowskiego Oddziału PAN, Warszawa-Kraków, s. $17-25$.

Misztal S., Zioło Z. [red.] (1998), Dorobek polskiej geografii przemystu w badaniach ośrodków akademickich, Komisja Geografii Przemysłu PTG, Wyd. Krakowskiego Oddziału PAN, Warszawa-Kraków.

Niżnik A., Makieła Z. (1987), Treści nauczania geografii przemysłu w programach kształcenia geografów w Czechosłowacji, [w:] Z. Zioło (red.), Geografia przemystu w akademickim kształceniu nauczycieli, Centralny Ośrodek Metodyczny Studiów Nauczycielskich WSP, „Materiały i Sprawozdania”, nr 14, Wyd. Naukowe WSP w Krakowie, Kraków, s. 84-89.

Pakuła L., Zioło Z. (1987), Treści kształcenia w zakresie geografii przemysłu przekazywane na wykładach, [w:] Z. Zioło (red.), Geografia przemysłu w akademickim kształceniu nauczycieli, Centralny Ośrodek Metodyczny Studiów Nauczycielskich WSP, „Materiały i Sprawozdania", nr 14, Wyd. Naukowe WSP w Krakowie, Kraków, s. 58-64.

Piskorz S. (1987), Treści z zakresu geografii przemystu w nowych programach szkoty podstawowej i średniej, [w:] Z. Zioło (red.), Geografia przemystu w akademickim kształceniu nauczycieli, Centralny Ośrodek Metodyczny Studiów Nauczycielskich WSP, „Materiały i Sprawozdania", nr 14, Wyd. Naukowe WSP w Krakowie, Kraków, s. 46-57.

Straszewicz L. (1957), Kompleks przemysłowy Łodzi, „Przegląd Geograficzny”, t. 29, z. 4, s. 741-777.

Straszewicz L. (1963), Aglomeracja Paryża, „Przegląd Geograficzny”, t. 35, z. 4, s. 591-614.

Straszewicz L. (1965a), Aglomeracja Londynu, „Przegląd Geograficzny”, t. 37, z. 1, s. 3-28.

Straszewicz L. (1965b), Francuski przemyst samochodowy, „Czasopismo Geograficzne”, t. 36, z. 3, s. 301-303.

Straszewicz L. (1966), Aglomeracja Berlina, „Przegląd Geograficzny”, t. 38, z. 1, s. 77-105.

Straszewicz L. (1969a), Aglomeracja Moskwy, "Przegląd Geograficzny”, t. 41, z. 2, s. 179-210.

Straszewicz L. (1969b), Rzym jako wielka metropolia świata, „Przegląd Geograficzny”, t. 41, z. 4, s. 623-650.

Straszewicz L. (1970), Rola przemysłu w rozwoju sieci miast, "Zeszyty Naukowe Uniwersytetu Łódzkiego", Ser. II, z. 18, s. 3-19.

Straszewicz L. (1972), Wielkie stolice Europy, Warszawa.

Straszewicz L. (1980), Lizbona, „Przegląd Geograficzny”, t. 52, z. 4, s. 743-759.

Straszewicz L. (1981), Aglomeracja Madrytu, „Przegląd Geograficzny”, t. 53, z. 2, s. 259-321.

Straszewicz L. (1986), Miejsce geografii przemystu w systemie nauk i studiów geograficznych, "Acta Universitatis Lodziensis", Folia Geographica 7, s. 25-33.

Straszewicz L. (1987a), Geografia przemysłu jako nauka i dyscyplina nauczania, [w:] Z. Zioło (red.), Geografia przemystu w akademickim ksztatceniu nauczycieli, Centralny Ośrodek Metodyczny Studiów Nauczycielskich WSP, „Materiały i Sprawozdania”, nr 14, Wyd. Naukowe WSP w Krakowie, Kraków, s. 8-13.

Straszewicz L. (1987b), Lyon - przemiany funkcjonalne wielkiej metropolii regionalnej Europy Zachodniej, „Acta Universitatis Lodziensis”, Folia geographica 8, s. 131-163. 
Stryjakiewicz T. (1987), Kierunki badawcze geografii przemystu w Polsce w latach 1945-1980, [w:] Z. Zioło (red.), Geografia przemystu w akademickim kształceniu nauczycieli, Centralny Ośrodek Metodyczny Studiów Nauczycielskich WSP, „Materiały i Sprawozdania”, nr 14, Naukowe WSP w Krakowie, Kraków, s. 22-45.

Wilczyński W. (2011), Ideowe źródła i tożsamość geografii, Wyd. Naukowe Uniwersytetu Pedagogicznego, Kraków.

Zawadzki S. M. (1973), Polska, przestrzeń, społeczeństwo, PWE, Warszawa.

Zikandeloff W. (1987), Koncepcje ćwiczeń z geografii przemystu w Wyższej Szkole Pedagogicznej w Dreźnie, [w:] Z. Zioło (red.), Geografia przemysłu w akademickim kształceniu nauczycieli, Centralny Ośrodek Metodyczny Studiów Nauczycielskich WSP, „Materiały i Sprawozdania", nr 14. Wyd. Naukowe WSP w Krakowie, Kraków.

Zioło Z. [red.] (1987), Geografia przemystu w akademickim ksztatceniu nauczycieli, Centralny Ośrodek Metodyczny Studiów Nauczycielskich WSP, „Materiały i Sprawozdania”, nr 14, Wyd. Naukowe WSP w Krakowie, Kraków.

Zioło Z. (1996a), Miejsce mezoekonomii w ekonomii, [w:] K. Górka (red.), Rola mezoekonomii w rynkowym systemie zarzadzania gospodarki. Księga Jubileuszowa dla uczczenia 50-lecia pracy naukowo-dydaktycznej Profesora Józefa Gajdy, Akademia Ekonomiczna w Krakowie, Kraków, s. 55-58.

Zioło Z. (1996b), Model funkcjonowania przestrzeni geograficznej i jego znaczenie dla gospodarki przestrzennej, [w:] U. Wich (red.), Gospodarka, przestrzeń, środowisko, UMCS w Lublinie, pod patronatem Komitetu Przestrzennego Zagospodarowania Kraju PAN, Lublin, s. 183-191.

Zioło Z. (1997), Miejsce struktury przestrzennej przemystu w przestrzeni geograficznej, [w:] Geografia, człowiek, gospodarka. Profesorowi Bronisławowi Kortusowi w 70. rocznice urodzin, Kraków, s. 125-132.

Zioło Z. (1999a), Model badań procesu transformacji elementów w przestrzeni geograficznej, [w:] I. Jażewicz (red.), Wspótczesne problemy przemian strukturalnych przestrzeni geograficznej (ksiażka dedykowana Profesorowi Eugeniuszowi Rydzowi w 70. rocznice urodzin), Akademia Pomorska w Słupsku, Słupsk, s. 103-117.

Zioło Z. (1999b), Model funkcjonowania przestrzeni geograficznej jako próba integracji badań geograficznych, [w:] A. Lisowski (red.), Geografia na przełomie wieków - jedność w różnorodności, Wydział Geografii i Studiów Regionalnych Uniwersytetu Warszawskiego, Warszawa, s. 122-131.

Zioło Z. (2003), Przestrzeń geograficzna jako miejsce realizacji idei ładu przestrzennego, [w:] T. Ślęzak, Z. Zioło (red.), Społeczno-gospodarcze i przyrodnicze aspekty ładu przestrzennego, „Biuletyn KPZK PAN”, z. 205, s. 25-43.

Zioło Z. (2010), Wptyw relacji nauk geograficznych i ekonomicznych na kształtowanie gospodarki przestrzennej, [w:] T. Kudłacz, J. Wrona (red.), Geografia w naukach ekonomiczno-przestrzennych, „Studia i Prace Uniwersytetu Ekonomicznego w Krakowie”, Kraków, s. 61-71.

Zioło Z. (2011), Problemy kształtowania przestrzeni geograficznej, [w:] Z. Długosz, T. Rachwał (red.), Priorytety badawcze i aplikacyjne geografii polskiej, Uniwersytet Pedagogiczny im. Komisji Edukacji Narodowej w Krakowie, Kraków, s. 26-42.

Zioło Z. (2014), The Concept of Geographical Space, „,Annales Universitatis Paedagogicae Cracoviensis" 155, Studia Geographica V, red. S. Kurek, T. Rachwał, Wyd. Naukowe Uniwersytetu Pedagogicznego, Kraków, s. 6-22.

Zbigniew Zioło, prof. dr hab., Podkarpacka Szkoła Wyższa im. bł. ks. W. Findysza w Jaśle 